\title{
The effect of (Kettlebell) exercises to improve some physical abilities and the level of skill and digital performance of shot-put players with cerebral palsy \\ "Dr/ Fatma Sayed Abd el Alim Muhamed Ajlan \\ Introduction:
}

The civilization of nations and societies is measured by the care and attention it provides to special groups, and perhaps the most prominent of them is the handicapped group with cerebral palsy, as they are citizens with their capabilities and roles, and they have the right to obtain their rights adequately.

Magdy Aziz (2013) and Rida Abdel Badi '(2012) mention that the perception of the disabled with cerebral palsy has changed in recent times, so societies have shown interest in them in one way or another, and the services provided to them are no longer limited to in the field of care and simple training, it now aims to educate, train and prepare them for beneficial jobs. The social outlook towards them no longer focuses on the aspects of their disability, but rather takes into account what is available to them in terms of capabilities. (11:25) $(5: 82)$

Both Kamal Morsi (2005) and Farouq Al-Rousan (2010) indicate that people with cerebral palsy have clear deficiencies in motor development and the skills it includes such as walking, balance and other motor skills that require control, accuracy and muscular compatibility. The nervous system, and this deficiency leads to a clear

weakness of perception, so that he is not able to arrange the stimuli in his environment properly or even to classify and analyze them, which makes him unaware of many vocabularies in his environment and how to deal with it, which results in some behavioral problems and emotional disorders such as negativity, anxiety, tension and withdrawal. $(10: 58)(9: 38)$

Lefort (2006) also indicated that disabled people with cerebral palsy have a remarkable degree of ability to perform movement properly, and therefore they are in constant need of training, support, follow-up, intensive care and attention from specialists. (19:11)

"Salem Muhammad AlManasri" (2009 AD) indicates that cerebral palsy is a damage to the brain, and the injury may occur before birth, during childbirth, or in the first years of life. The percentage of children with cerebral palsy during childbirth is $(86 \%)$ of cases and the percentage of $(14 \%)$ occur after birth as a result of trauma and trauma to the child's head, accidents and tumors that affect the brain. (6:25)

Ahmed Al-Zoghbi (2007) defines cerebral palsy as "one of the

"Assistant professor at sport recreation dep., faculty of physical education, Mansoura university of Egypt Lecturer in the Department of field and track competitions training, Faculty of Physical Education for Girls. Helwan University.

Assiut Journal For Sport Science Arts 
manifestations of movement disability resulting from brain injury early in the child's life, especially in the period of incomplete growth of the cerebral cortex responsible for movement. What is meant by cerebral palsy is the deficit in the neuromuscular capacity resulting from Brain injury, which leads to a lack of ability to control voluntary muscles, and the manifestations of cerebral palsy are the inconsistency of the shape of the motor skills of the affected individual, or the movement of the muscles is too fast or too slow or a mixture of both, and cerebral palsy may have reported sensory disturbances, as well as Speech and language disorders associated with the victim. (1-55)

Issam Hamdy (2007 AD) states that brain injury varies from person to person according to the location and size of the injury. This effect may take different forms. Muscle harmony depends on the signals sent from the brain. This harmony is what keeps the body in a certain fixed position, which makes the movement regular and balanced. (8:65)

Sharaf Abdel Hamid (2001) mentions sport activities as an effective mediator through which people with this type of disabilities can improve their physical, personal and social skills, as it adapts them and the sense of life alongside their families and strengthens their sense of belonging to the group. The most important of which is swimming, as psychologists and sociologists have placed it at the forefront of sports activities that help the disabled individual to be free, set out, and participate in recreational and group activities in which all segments of society participate. (7: 138)

Mufti Ibrahim (2013) mentions that sports training is a science based on foundations and principles through which the best levels and results can be achieved in all sporting events, and in order to reach that goal, a deep understanding of the foundations and principles of this science is necessary, in addition to shedding light on everything that is new and developed. In the field of sports training and its applications. (12: 187)

Hassan Abd Al-Salam (2013) and Hanan Al-Sayed Abdel-Fattah (2000) add that the basis for athletic progress is to raise the level of physical abilities required by a sporting event. Take advantage of the capabilities and capabilities that they have so that each of them has a role in life as a citizen with duties that he performs to be part of the development plans of the society in which he lives. (16:3) (25:4)

The field and track competitions are considered one of the most important sports that translate and reflect in an objective manner the extent of sports progress, as they are characterized by the objectivity of evaluating human achievement in the form of digital levels from times in the running and walking competitions and to points in complex competitions. (21)

The shot-put competition also occupies a prominent place among the field competitions, as it is practiced in all the age stages specified by the competition law for both sexes and for all groups of society and people with special needs. 
Gold vaster (2014) adds that it is one of the elements of the physical fitness of the putter leg (muscular capacity of the arms, muscular capacity of the two legs, muscular strength of the arms, muscular strength of the two legs, flexibility, balance, compatibility), which are the elements that distinguish one player from another and are decisive. In the results of competitions and determines the level of skill performance, and by focusing on the element of strength, although it is considered the second element in terms of importance for the elements of special physical fitness, but the element of strength is the basis in the components of physical performance, which is related to the element of speed to produce the strength characteristic of speed. $(17: 28)$

Bastwissi Ahmed (2014) indicates that the level of the shot putter rider depends physically on the extent of his muscle strength, balance, and speed to launch the tool at the highest possible speed at the moment of pushing, especially after the completion of the pushing process, where the distance of thrusting or throwing is determined by that acquired speed Speed is the product of power, and there is no speed without power. Thus, force increases the speed of performance from the beginning of the movement until the start. (2: 413)

Mufti Ibrahim (2013) states that in muscle strength training, attention must be paid to muscle strength training for muscles that actively participate in specialized sports skills. (12-196)

Brittany and Randal \& Brittany (2015) state that one of the training tools used in the development of the strength element is the use of kettlebell, which is made of metal in the form of a large jug, and is used in many physical and skill training. It is one of the free weights that appeared in Russia at the beginning of the nineties and was used by the Russian special forces for a long time until it spread in the rest of the world in various forms according to the training objective for which it is used. (16:11)

One of the most important features of (Kettlebell) is that it is available in different sizes from (1: 50) $\mathrm{kg}$, and there are many different shapes, one of which is designed in the shape of a jug with different weight categories and this is the most widespread form, and the other form consists of an Alcatel handle and cylinders of different weights are installed in it. (16:12)

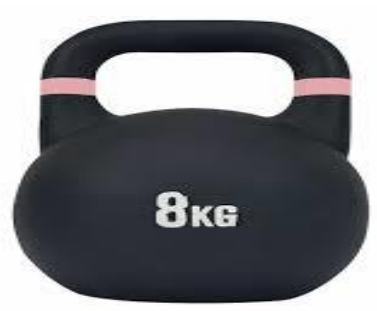

Figure No. (1)

Assiut Journal For Sport Science Arts 
Nick Beltz (2013) and Scott Gaines (2003) indicate that (Kettlebell) is used in the development of many physical abilities such as (strengthability- balance- endurance- agility), and it helps reduce the chances of injury as a result of It is used to improve muscle tone, it is used to improve the muscular balance and muscle strength of different muscle groups, and it is used to develop physical fitness better than regular weight forms, dumbbells and bar. (18:10) (20:14)

Kamal Abdel Hamid (2011) adds that despite the tremendous development in the field of sports training in general and weight training in particular, some coaches do not pay attention to this type of training during their training programs, and that the most important kinetic goals for coaches are to overcome the deficiencies of the players and develop General, Special, and Skill Physical Abilities (22)

\section{Previous studies:}

1- The study of "Hani Jafar" (2018 AD) (14) entitled "The effect of training using iron ball (Kettlebell) on some special physical variables and the level of performance of a group of back throw movements among wrestling players." The researcher used the experimental method to design two groups, one experimental and the other controlling. The research in the emerging wrestlers from the Sohag University Wrestling team and the number of the research sample was (28) wrestlers, they were randomly distributed into two groups, one of them experimental and included (10) wrestlers and the other controlling and included (10) wrestlers and one of the most important results was that the effect of training using (Kettlebell) It was better than the traditional program training in improving the physical variables and the effectiveness of the skill performance of the group of back throw movements of the wrestlers.

2- $\quad$ The study "Yusra Atef Sharaf" (2009 AD) (15) entitled "Advanced Concepts in the Treatment and Rehabilitation of Patients with Cerebral Palsy" The study aimed to identify modern basic methods in rehabilitating children with cases of cerebral palsy. The researcher used the descriptive approach of survey studies by following up on patient records. Research on children attending Assiut University Hospital, and one of the most important results was that the use of rehabilitative exercises and medical splints had a positive effect on improving the level of standing and balance of children with cerebral palsy cases.

3- The study "Salem Muhammad Al-Manasri" (2009 A.D.) (6) entitled "A study of the pattern of cerebral palsy cases in children visiting the Neurological Diseases Clinic of Alexandria University Children's Hospital." The study aimed to identify the existing patterns of cerebral palsy cases that are frequent at Alexandria University Children's Hospital. Descriptive tracer survey studies through records. The research sample included children attending Alexandria University Children's Hospital and those with cerebral palsy. One of the most important results was that spastic 
(congenital) cerebral palsy is one of the most common types of cerebral palsy in Egypt.

4- The study "Muhammad Abdul Hamid Muhammad" (2009 AD) (13) entitled "The effect of a proposed rehabilitation program on some physical variables in children with cerebral polio (CP)" The study aimed to identify the effect of a proposed rehabilitation program on some physical variables in children with polio the researcher used the experimental approach by designing the pre-post measurement for one experimental group. The research sample included (30) children with congenital cerebral palsy and attending physiotherapy centers in Menoufia governorate. Flexibility) and the length of the affected muscles.

\section{Research aims:}

The research aims to investigate the effect of (Kettlebell) exercises on: 1- Some physical changes for the shotput player with cerebral palsy.

2- The skill and numerical level of shot-put players with cerebral palsy.

\section{Research hypotheses:}

1- There are statistically significant differences between the premeasurement and the postmeasurement in some physical variables of the cerebral palsy shot-put player and in favor of the postmeasurement.
2- There are statistically significant differences between the premeasurement and the postmeasurement in the level of skill and numerical performance of the cerebral palsy shot-put player in favor of the post-measurements.

\section{Search procedures:}

\section{Research Methodology:}

The researcher used the experimental method by designing one experimental group to suit the nature of the research.

\section{Research Community and Sample:}

The community and the research sample consisted of a one shot-put player for the Egypt national team with cerebral palsy category (CP) at the First Settlement Youth Center in Cairo.

\section{Proposed program design:}

By referring to previous studies, scientific references, theoretical framework, opinions of experts, scientists and trainers in the field of sports for people with cerebral palsy, the researcher designed a proposed training program using the iron ball (Kettlebell)

Research measurements and tests:

The researcher's stature took the basic measurements of growth variables (age, height, weight), the physical variables under investigation, and the level of skill and digital performance in the shot-put race for those with cerebral palsy.

Table (1)

It shows basic measurements for a player age, height and weight $\mathrm{N}=1$

\begin{tabular}{c|c|c|c}
\hline \hline NUM & Variable & Discrimination & scaling \\
\hline \hline $\mathbf{1}$ & Age & Year & 24 \\
\hline $\mathbf{2}$ & Length & $\mathrm{Cm}$ & 184 \\
\hline $\mathbf{3}$ & Weight & $\mathrm{Kg}$ & 101 \\
\hline \hline
\end{tabular}

Table (1) shows the basic data for the growth variables for the study sample

Assiut Journal For Sport Science Arts 
Table (2)

It shows the physical variables of the player used in the search

\begin{tabular}{|c|c|c|c|c|c|c|}
\hline NUM & $\begin{array}{l}\text { Physical } \\
\text { variables }\end{array}$ & $\begin{array}{c}\text { Unit of } \\
\text { measurement }\end{array}$ & $\begin{array}{c}\text { Test } \\
\text { name }\end{array}$ & $\begin{array}{c}\text { Pre } \\
\text { measurement }\end{array}$ & $\begin{array}{c}\text { Post } \\
\text { measurement }\end{array}$ & $\begin{array}{c}\text { Level of } \\
\text { improvement \% }\end{array}$ \\
\hline 1 & $\begin{array}{c}\text { Muscle } \\
\text { ability test } \\
\text { for arms }\end{array}$ & meter & $\begin{array}{c}\text { He threw a } \\
\text { medical } \\
\text { ball in } \\
\text { front of the } \\
\text { body } 3 \mathrm{~kg} .\end{array}$ & 7.60 & 8.5 & $11.84 \%$ \\
\hline 2 & $\begin{array}{c}\text { Muscle } \\
\text { ability test } \\
\text { for two men }\end{array}$ & meter & $\begin{array}{l}\text { The broad } \\
\text { jump of } \\
\text { standing } \\
\text { with the } \\
\text { two men } \\
\text { together. }\end{array}$ & 2.20 & 2.50 & $13.63 \%$ \\
\hline 3 & $\begin{array}{c}\text { Muscle } \\
\text { strength test } \\
\text { for arms }\end{array}$ & $\begin{array}{l}\text { Number of } \\
\text { attempts }\end{array}$ & $\begin{array}{c}\text { Double- } \\
\text { arm test of } \\
\text { Leaning } \\
\text { prone } \\
\text { position } \\
\text { during } \\
(30 \mathrm{w})\end{array}$ & 22 & 28 & $27.27 \%$ \\
\hline 4 & $\begin{array}{c}\text { Flexibility } \\
\text { test }\end{array}$ & $\mathrm{Cm}$ & $\begin{array}{l}\text { Bend the } \\
\text { trunk in } \\
\text { front of } \\
\text { the long } \\
\text { seating }\end{array}$ & 46 & 49 & $6.52 \%$ \\
\hline 5 & $\begin{array}{c}\text { Compatibility } \\
\text { test }\end{array}$ & second & $\begin{array}{c}\text { Transition } \\
\text { test over } \\
\text { numbered } \\
\text { circuits }\end{array}$ & 12.6 & 13.1 & $3.96 \%$ \\
\hline
\end{tabular}

It is clear from Table (2) that the extent of improvement that occurred to the physical variables of the study sample as a result of implementing the program.

Assiut Journal For Sport Science Arts 
Table (3)

The form to assess the skill level of the shot-put player - score (10)

\begin{tabular}{|c|c|c|c|c|c|c|}
\hline num & \multicolumn{2}{|c|}{ Technical stages } & Educational points & Degree of pre & Degree of Post & Improvement \\
\hline \multirow[t]{3}{*}{1} & \multirow{3}{*}{$\begin{array}{l}\text { Number } \\
\text { stage } \\
\text { (boot) }\end{array}$} & $\begin{array}{l}\text { A- Catch the } \\
\text { put and } \\
\text { carry it }\end{array}$ & $\begin{array}{l}\text { - The fingers spread behind the put } \\
\text { and the put is based on the health of } \\
\text { the fingers and does not settle in the } \\
\text { palm of the hand. } \\
\text { - the put is placed under the lower } \\
\text { jaw over the c,ollarbone. }\end{array}$ & 0.5 & 0.75 & (n) \\
\hline & & $\begin{array}{c}\text { B. First } \\
\text { anchor mode }\end{array}$ & $\begin{array}{l}\text { (Starting from the back of the circle) } \\
\text {-The anchor foot is heavily bent } \\
\text { from the knee joi } \\
\text {-Back facing the throwing clip } \\
\text { and curve dow } \\
\text { - The axis of the shoulders parallel } \\
\text { to the earth } \\
\text {-The weight of the body is loaded } \\
\text { on the anchor man }\end{array}$ & $\begin{array}{c}0.0 \\
0.25 \\
0.25 \\
0.25\end{array}$ & $\begin{array}{l}0.25 \\
0.5 \\
0.5 \\
0.75\end{array}$ & $\begin{array}{l}25 \% \\
100 \% \\
100 \% \\
200 \%\end{array}$ \\
\hline & & C. Partridge & $\begin{array}{l}\text { (Moving across the circle) } \\
\text { The argument begins with the first } \\
\text { anchor and ends with the second. }\end{array}$ & 0.0 & 0.75 & $75 \%$ \\
\hline 2 & $\begin{array}{l}\text { The basic } \\
\text { stage } \\
\text { (3) Stairs }\end{array}$ & $\begin{array}{c}\text { A. Second } \\
\text { anchor mode }\end{array}$ & $\begin{array}{l}\text { (Begins by placing the anchor foot } \\
\text { on the ground at the center of the } \\
\text { circle at the end of the argument) } \\
\text { - Put the man's free foot at the level } \\
\text { of the anchor heel } \\
\text { - The anchor foot moves to the } \\
\text { center of the circle, almost the end } \\
\text { of the partridge, with the angle } \\
\text { between the thigh and the leg less } \\
\text { than } 90 \text { degrees. } \\
\text { - Up the man's free foot ground } \\
\text { after the man's foot anchored } \\
\text { - The vertical projector of the } \\
\text { center of gravity of the body must } \\
\text { be located in the second anchor } \\
\text { position on the anchor foot comb. } \\
\text { - The upper body should be in } \\
\text { position as it was at the beginning } \\
\text { of the movement, which is that the } \\
\text { back is facing the throwing clip. } \\
\text { - When you reach the payment position, } \\
\text { the left side of the basin is in the } \\
\text { direction of the throwing section. } \\
\text { - The yield-bearing arm is below } \\
\text { the lower jaw and the highest } \\
\text { collarbone }\end{array}$ & $\begin{array}{l}0.0 \\
0.25 \\
0.0 \\
0.0 \\
0.0 \\
0\end{array}$ & $\begin{array}{l}0.25 \\
0.25 \\
0.25\end{array}$ & $\begin{array}{l}25 \% \\
25 \% \\
25 \%\end{array}$ \\
\hline
\end{tabular}

\section{Assiut Journal For Sport Science Arts}


Follow Table (3)

The form to assess the skill level of the shot-put player - score (10)

\begin{tabular}{|c|c|c|c|c|c|c|}
\hline \multirow[t]{2}{*}{ num } & \multicolumn{2}{|c|}{ Technical stages } & Educational points & $\begin{array}{l}\text { Degree of pre } \\
\text { measurement }\end{array}$ & $\begin{array}{l}\text { Degree of Post } \\
\text { measurement }\end{array}$ & $\begin{array}{c}\text { Improvement } \\
\text { rates }\end{array}$ \\
\hline & & $\begin{array}{l}\text { B- Payment } \\
\text { mode }\end{array}$ & $\begin{array}{l}\text { - The body's rotation begins in the } \\
\text { direction of the throwing section. } \\
\text { - The push-foot kick begins } \\
\text { upwards as it rotates inward to the } \\
\text { side of the throwing section. } \\
\text { - The faux-bearing arm continues } \\
\text { its previous position during rotation } \\
\text { and the chest becomes facing the } \\
\text { throwing clip } \\
\text { - The free arm helps to rotate to the } \\
\text { side of the throwing section } \\
\text { - After the chest is facing the } \\
\text { throwing clip, the pushing arm is } \\
\text { firmly in the right direction to push } \\
\text { the put forward. } \\
\text { - Extend all parts of the body with } \\
\text { the foot of the anchor man up with } \\
\text { its rotation inside the side of the } \\
\text { throwing section }\end{array}$ & $\begin{array}{l}0.25 \\
0.0 \\
0.0 \\
0.0 \\
0.25 \\
0.0\end{array}$ & $\begin{array}{l}0.25 \\
0.25\end{array}$ & $\begin{array}{l}0 \% \\
25 \% \\
25 \% \\
25 \% \\
0 \%\end{array}$ \\
\hline 3 & $\begin{array}{l}\text { Final stage } \\
\text { (final) } \\
\text { (2) Degrees }\end{array}$ & A- Balance & $\begin{array}{l}\text { For successful payment, the player must focus } \\
\text { on stability in the circle, maintaining balance } \\
\text { and not getting out of the circle. }\end{array}$ & 0.5 & 1.5 & $200 \%$ \\
\hline
\end{tabular}

Table (3) shows the degree of pre and post measurement, the difference between them, and the rate of improvement for each of the technical stages and the educational

Table (4)

Digital shot-put player rating form

\begin{tabular}{c|c|c|c}
\hline \hline num & $\begin{array}{c}\text { Digital level of pre } \\
\text { measurement }\end{array}$ & $\begin{array}{c}\text { Digital level of Post } \\
\text { measurement }\end{array}$ & Improvement rates \\
\hline \hline 1 & 6 & 8 & $33.333 \%$ \\
\hline \hline
\end{tabular}

Table (4) shows that there is an improvement between the premeasurement at the beginning of the training program for the digital level of the player in the shot-put race and the post measurement at the end of the points of the shot-put skill for the research sample, where the percentage improvement ranged between the percentage from $(0 \%-200 \%)$

training program with an estimated rate of $(33.33 \%)$

Data collection tools and means:

First: Instruments and measuring devices used under investigation:

- Stopwatch to the nearest 1/100 s.

$$
\text { post measurement at the end of the }
$$

Assiut Journal For Sport Science Arts 
- Medical balance.

- tape measure.

- $3 \mathrm{~kg}$ medicine balls.

- Kettlebell weights $8 \mathrm{~kg}, 10 \mathrm{~kg}$

- put weighs $6 \mathrm{~kg}$.

- Color chalk.

The field and circle of shot put.

Second: The physical and skill tests in question: Attachment (4)

1- The muscular capacity test of the arms.

2- Test the muscular capacity of the two leg.

3 - The muscle strength test of the arms.

4- Flexibility test.

5- Compatibility test.

Third: scientific transactions for the tests used:

The proposed training program:

1- Foundations of developing the program:

After reviewing the previous studies and scientific references, the researcher reached some points through which the training program could be developed, and when applying resistance training using the (Kettlebell) tool, the following was adopted:

- Taking into account the characteristics of the sample and its medical classification in terms of physical and health.

- That the program achieves the goals for which it was set.

- Establishing the training program using the scientific foundations related

Table (5)

It shows the physical loads and intensity used in the training program

\begin{tabular}{c|c|c|c|c}
\hline \hline load & Medium & Higher & $\begin{array}{c}\text { Less than } \\
\text { maximum }\end{array}$ & maximum \\
\hline \hline intensity & $50-70 \%$ & $71-80 \%$ & $81-90 \%$ & $91-100 \%$ \\
\hline \hline
\end{tabular}

Assiut Journal For Sport Science Arts to carrying the appropriate training for the dental stage and the medical classification of the sample.

Pay attention to choosing the appropriate exercises for the sample.

Taking into account the timing of physical and skill tests.

- Graduation using iron ball weights.

- At the end of the unit, implementation of exercises for stretching and flexibility to obtain relaxation in order to return the muscles to a normal state.

Forming the training load for the training program:

- The researcher determined the intensity of the exercises using the (Kettlebell) attached (5) by calculating the maximum number of repetitions for each exercise, or determining the maximum time for stability with the tool and recording it in a special card for the player to determine the appropriate intensity for the proposed exercises attached (6), according to the training program.

The duplicates were determined by the following equation: -

(Maximum number achieved* Required intensity)/100

(Maximum time achieved* Required intensity)/100

The percentage of loads was determined to determine the repetitions and performance periods as follows: 
- The training groups were determined between (2-4) groups, with rest periods between repetitions (30 seconds) and with breaks between groups (1-3) s.

-The training loads were determined during the training units by (16) training units:

3- Chronology of the training program:
- The researcher set the time division in proportion to the goal of the study, as the program was implemented for a period of (12) weeks by (3) weekly training units a day (SaturdayTuesday-Friday) of each week, so the number of units for the program became (36) training units, and a time Unit (90) minutes was divided as follows:

Table (6)

It shows the time distribution of the training units

\begin{tabular}{c|c|c}
\hline \hline Time & Unit parts & Group work \\
\hline \hline $10 \mathrm{~min}$ & warm up & Warm-up and lengthening exercises \\
\hline $30 \mathrm{~min}$ & $\begin{array}{c}\text { General and private physical } \\
\text { numbers }\end{array}$ & Proposed program training \\
\hline $40 \mathrm{~min}$ & Training Skills & Skilled exercises \\
\hline $10 \mathrm{~min}$ & Final Part & Prolongation and calming exercises \\
\hline \hline
\end{tabular}

Applied procedures of the training program:

Pre measurements:

- The researcher made the premeasurements of the research sample in the physical variables in question and the level of skill and numerical performance of the shot put on Friday and Saturday on January 3-4, 2020 at the Al-Jelleh Stadium in the First Settlement Youth Center, Cairo Governorate.

\section{Application of the program:}

- The training program was applied to the Egyptian national team player with cerebral palsy category $(\mathrm{CP})$, where the program was implemented by the researcher and assisted some administrators at the Youth Center from Friday 10/1/2020 AD to Friday 3/4/2020.

Assiut Journal For Sport Science Arts
Dimensional measurements:

Dimensional measurements were made in the same order and conditions in the pre-measurements, on Tuesday and Wednesday 7/8-4-2020.

\section{Statistical treatments:}

An equation was used to calculate improvement rates as follows:

((Post measurements -Pre measurements)/ Pre measurements) $* 100$

\section{Conclusions:}

1- Some of the physical variables under investigation have improved as a result of using Kettlebell resistance training.

2- Improving the skill level and digital as a result of resistance training using the (Kettlebell).

3- The use of the proposed training program in Kettlebell led to an improvement in the digital level as a result of the improvement in the skill level and physical abilities of the shotput race. 
Recommendations:

1- Using Kettlebell resistance training because it has a positive effect on improving some physical variables for those who have no shot put with cerebral palsy.

2 - Diversity in the use of weight training such as (Kettlebell) or others in the direction of muscular work by no shot put for people with cerebral palsy.

3- The use of auxiliary and alternative tools in training to improve the skill level and digital shot-put players for those with cerebral palsy.

4- Conducting similar studies at different stages of his life.

6- Conducting similar studies on different physical and skill variables.

\section{References:}

First: Arabic references:

1- Ahmad Al-Zoghbi: (2007) Mobility Disability and Cerebral Palsy, Al Hadithah House for Printing and Publishing, Cairo

2- Bastwissi Ahmed Bastwissi: (2014) Foundations of Muscular Strength Development in the Field of Events and Sports, Al-Kitab Center for Publishing, Cairo.

3- Hassan Abdel Salam, Naglaa Fathy: (2013) The Kinetic Education System, Theories and Applications, Knowledge Foundation, Alexandria.

4- Hanan Al-Sayed Abdel-Fattah (2000): The basic (natural) movements of a child in the first stage of basic education as an entry point for field and field competitions from the age of (6-9 years), researching his promotion, Sports Education College for Girls, Heloun University, Cairo.
5- Rida Abdul-Badi Al-Sayed (2012): Quality in Education for People with Special Needs in Light of Some Arab and International Experiences, The New University House.

6- Salem Muhammad Al-Manasri: (2009) A study of the pattern of cerebral palsy cases in children visiting the Neurological Diseases Clinic of Alexandria University Children's Hospital, Master Thesis, Faculty of Medicine, Alexandria University, 2009 AD.

7- Sharaf Abdul Jameed: (2001), Physical and Kinetic Education for Normal Children and Challenges with Disabilities, Between Theory and Practice. Heliopolis - Cairo: The Book Center for Publishing.

8- Essam Hamdi Al-Safadi (2007): Movement disability and cerebral palsy, "Al-Yazouri Scientific Publishing and Distribution House, Amman.

9- Farouk Al-Rousan: (2010) Introduction to Mental Disability, Dar Al-Fikr for Publishing and Distribution, Syria.

10- Kamal Morsi: (2005) A reference in mental retardation, Cairo, Egyptian Universities Publishing House.

11- Magdy Aziz Ibrahim (2013): Curricula for teaching people with special needs in light of human, social and cognitive requirements, AngloEgyptian Library, Cairo.

12- Mufti Ibrahim (2013 AD): The Comprehensive Reference in Sports Training - Practical Applications, Dar Al-Kitab Al-Hadith, Cairo.

13- Muhammad Abd al-Hamid Muhammad: (2009) "The Impact of a Proposed Rehabilitation Program on 
Some Physical Variables in Children Affected by Cerebral Polio (C.P)" Master Thesis, College of Physical Education, Menoufia University, 2009 AD.

\section{4- Hany Jafar Abdullah Al-Sadiq} (2018): The effect of training using kettlebell on some special physical variables and the level of performance of the back throw movements group among wrestling players, The Scientific Journal of Education, Physical Sciences and Sports Sciences, June issue, Faculty of Physical Education for Boys, Helwan University.

15- Yusra Atef Sharaf: "Advanced Concepts in the Treatment and Rehabilitation of Patients with Cerebral Palsy", Master Thesis, Faculty of Medicine, Assiut University, 2009 AD.

Second: Foreign References.

16- Brittany A. Rajala and Randall L. Jensen (2015): emg of lower limb muscles during kettlebell exercises, 33rd International Conference on Biomechanics in Sports, Poitiers, France, June 29 - July 3
17- Gold vasster D., kkebs D. E mgibbon C. A (2014): occupation and visual/ Vestibular iteration in vestibular rehabitiaion", oto lagynol head neck surg Apr. 18- Nick Beltz, Dustin Erbes, John P.porcari,ray Martinez, Scott Doberste in, Carl Foster(2013):The Effect of a period of TRX Training on lipid profile and body Composition in over wight Women, volume 2,issue 2,December,Journal of fitness research program design .National strength and conditioning Association Journal ,33(6),86.

19-Lefort, J. (2006): Social interaction skills children with autism a script fading procedure for beginning readers. journal of applied. Analysis.

20-Scott Gaines (2003): Benefits and limitations of Functional Exercise, Vertex fitness, NESTA, USA, P214.

Third: internet sites.

21=http://main.eulc.edu.eg/eulc_v5/Li braries/Thesis/BrowseThesisPages.asp $\mathrm{x} ? \mathrm{fn}=$ PublicDrawThesis\&BibID $=1248$ 7830

22-http://darelfikrelarabi.com/book. 